Bryn Mawr College

Scholarship, Research, and Creative Work at Bryn Mawr

College

Political Science Faculty Research and Scholarship

Political Science

2012

\title{
Revisiting the Ungovernability Debate: Regional Governance and Sprawl in the USA and UK
}

Carol Hager

Bryn Mawr College, chager@brynmawr.edu

(C) 2012 Urban Research Publication Limited

Let us know how access to this document benefits you.

Follow this and additional works at: http://repository.brynmawr.edu/polisci_pubs

Part of the Political Science Commons

\section{Custom Citation}

Hager, Carol. "Revisiting the Ungovernability Debate: Regional Governance and Sprawl in the USA and UK." International Journal of Urban and Regional Research 36, no. 4 (2012): 817-830.

This paper is posted at Scholarship, Research, and Creative Work at Bryn Mawr College. http://repository.brynmawr.edu/polisci_pubs/21

For more information, please contact repository@brynmawr.edu. 


\section{Revisiting the ungovernability debate: regional governance and sprawl in the USA and UK}

\section{(A) Introduction}

A return to the "crisis of the state" debate of the 1970s and 80s can help explain the failings of contemporary regional governance institutions in the USA and UK. The 1960s and early 70s saw unprecedented levels of political participation in Western democracies. The crisis consisted in the recognition that this wave of activism "nowhere led to political transformation or even to major reforms but only to dead ends and deadlocks" (Berger 1979: 27). Government actors (and many academics) in the USA and UK understood it as a crisis of ungovernability too many conflicting societal demands paralyzed governments. Their response was to divest the state of some responsibilities for service provision while leaving in place the agenda-setting power of the state in the UK and market actors in the USA. From the standpoint of many citizens, however, the crisis had more to do with the inappropriateness of government tools for solving problems of citizen participation and local quality of life. They wanted a genuinely participatory politics in which a full range of community values - both economic and noneconomic - could be taken into account in policy making. The neoliberal turn did little to address their concerns.

The move from command-and-control government to governance starting in the 1990s was partly a response to the impasse over the state. Governance institutions seemed to offer something for everyone: devolved, networked power, a focus on concrete problems, collaboration rather than conflict, and new relationships of trust between stakeholders and government. But these institutions have been quite controversial, and nowhere more so than in the fight against suburban sprawl. This article returns to the crisis of the state literature to help explain why, using the empirical example of regional land use planning in the USA and UK. 
The two countries approached the issue from opposite directions - policy making power resided largely in local market actors in the USA and in the central government in the UK. Both countries introduced collaborative regional planning institutions - regional as an antidote to fragmentation (USA) or overcentralization (UK) of planning authority, collaborative as a way to include stakeholders directly in negotiations on land use. I examine two of these: the East of England Regional Assembly and the New Jersey State Planning Commission. Despite their promise of a more cooperative, responsive politics, and their success at producing regional land use plans, these institutions are widely criticized as ineffectual and unrepresentative. The problems have partly to do with the design and scope of the institutions. The case studies also suggest a more meta-level explanation. I argue that the East of England Regional Assembly and the New Jersey State Planning Commission have inadvertently revived issues of power, accountability, and legitimation still simmering from the crisis of the state.

These governance institutions have shifted accountability for policy decisions downward from the center in the UK case, upward from the local level in the USA case - without shifting the underlying agenda-setting power of state and market, respectively. This makes sense as a response to a crisis of ungovernability (too many demands on the state). The case studies indicate, however, that the crisis may have been more about the failure of state and market to consider the full range of community values in policy making (inappropriateness). In that case, the regional institutions seem only to confirm the critique of power put forth by the protesters of the 1970s and 80s. American and British governments have offloaded conflict between economic and quality-of-life values to the regional level without granting the regional institution the power to resolve them. Moreover, the "post-political" focus of collaborative governance keeps conflict over values from being aired effectively within the collaborative bodies. It may thus remove these issues further from the influence of nonmarket stakeholders while couching 
them in the language of cooperation. Participants in current regional policy making become frustrated at the inability of collaboration to provide meaningful citizen participation that they believe would help alleviate sprawl. Thus the legitimation deficits of earlier years come again to the fore. In the absence of a means to contest these issues within the collaborative institutions, they are contested from the outside through protest.

(A) The crisis of the state and the origins of governance

Governance, as an institutional form and as a theoretical perspective, rose to prominence in the wake of the perceived crisis of the state in the 1970s. According to Suzanne Berger, three different critiques of the state converged during those years to create the atmosphere of crisis in Western Europe. One was the ungovernability or overload thesis, which held that too many conflicting societal demands were paralyzing the contemporary state. Another was the overgovernability thesis, which held that the contemporary state was all too powerful and intervened in society too much. The third, which I call the inappropriateness thesis, held "that the existence of the state with its current scope and attributes is incompatible with the realization of fundamental human aspirations (for ethnic self-determination, for participation, for preserving the natural environment, and so forth)" (Berger 1979: 34). Although the political unrest was less pronounced in the U.S., a similar sense of crisis pervaded American politics in the 1970s. The result was widespread citizen unrest from across the political spectrum.

The ungovernability thesis came mainly from the political Right. Samuel Huntington writes that, after the "democratic surge" of the 1960s, the increased scope of governmental activity combined with decreasing governmental authority to produce a sense of malaise: “The public develops expectations which it is impossible for government to meet. The activities - and expenditures - of government expand, but the success of government in achieving its goals seems 
dubious" (1975: 104; also Offe 1984: 65-87). The overgovernability thesis came mainly from the political Left. According to Claus Offe, the contemporary welfare state tries to limit conflict through corporatism and technocratic planning. At the same time, democratic political institutions, especially political parties, fail to facilitate substantive citizen participation. Thus, as the state looms ever larger in private life, it appears less accessible to citizens (1984: 174). The inappropriateness thesis was a variation of this one. The contemporary state, writes Manuel Castells, structures social life on behalf of capital, demoting the citizen to the status of consumer (1978: 33; also Marcuse 1964). This creates conflicts, adds David Harvey, over quality of life: "Capital seeks...to impose meanings conducive to the productivity of labor and to the consumption of the commodities that capitalists can profitably produce...But labor seeks its own meanings, partly derived out of a rapidly fading memory of artisan and peasant life, but also out of the ineluctable imperative to learn what it is to be human" (1985: 61).

What is striking, writes Berger, is that these very different diagnoses of the crisis all led to demands to reduce the scope of state authority (1979: 33-34). Ecological candidates in Europe and the U.S. advocated local self-management and cooperative organizations (Castells 1978: 1). The political Right adopted crisis language similar to that of the Left; the difference was that the former "see the source of crisis and what they wish to eliminate," writes Offe, "not in conditions of capitalist wage-labour but, rather, in the institutionalized arrangements of welfare state mass democracy" (Offe 1984: 66). The common call to dismantle the state "reflects a deep loss of confidence about the possibility of using the state to good end" (Berger 1979: 33-34).

The Thatcher and Reagan administrations' solutions to the crisis included divesting the state of some of its responsibilities for service provision. There was a shift in focus in the 1980s to the goal of economic efficiency. The 1990s saw an increased focus on community and social 
capital within the neoliberal framework, partly in response to market failures brought on by neoliberalism itself (Peck and Tickell 2002). As interest in formal political institutions declined, interest rose in policy solutions involving informal networks, in direct negotiations between societal and governmental actors, and in public-private partnerships. The emphasis on social capital reinforced new ways of conceptualizing political power "beyond the state" (Swyngedouw 2005). "Governance" departs from the idea of power as "a commodity rooted in particular institutions" to "more fluid ideas of power developed and negotiated between partners" (Taylor 2007: 299-300). Governance became the model for the "third wave" of regulatory reform beginning in the 1990s (Kraft 2009; Krueger and Gibbs 2008).

Paul Hirst describes governance as “a 'post-political' search for effective regulation and accountability" (2000: 13-14). It is problem-focused rather than ideological, collaborative rather than conflictual. Its proponents claim that collaboration promotes shared meaning and purpose, new ways of understanding as well as new practices among participants. Collaborative governance processes "help to develop a more deliberative democracy among a wider community and increase civic engagement" (Innes \& Booher 2003: 55). Mazmanian and Kraft note that collaborative governance is becoming the norm with issues, such as sustainability, which involve complex and interrelated systems and human activities. It is simply impossible to regulate each facet of the issue separately; solutions must be coordinated and negotiated among many actors (2009: 21-22). Collaborative institutions may provide new "political spaces" (Jonas \& While 2007) in which a range of growth and preservation goals can be negotiated together.

(A) Governance in land use planning

Our case studies of collaborative land use planning are situated in this third wave of regulatory reform. The U.S. and UK approached the issue from different directions. As Kevin 
Cox points out, the U.S. has a tradition of decentralized planning in which local economic interests mobilize state and local government in their support. The UK has a tradition of centralized planning in which the central state mobilizes resources to guide development and local authorities enjoy flexibility in local planning (2004: 247). The neoliberal turn in the U.S. involved an anti-regulation backlash by property interests and the abandonment of federal attempts at land use legislation (Weir 2000; Vig 2006). In Britain it involved an increased market orientation and at the same time a centralization of planning decisions that had been subject to local discretion (Allmendinger and Tewdwr-Jones 2000: 1381, 1384). Problems with the neoliberal approach became apparent as competition for resources intensified between communities (Peck and Tickell 2002: 386), threatening to accelerate the self-reinforcing cycle of decline in blighted urban areas and sprawl development in the suburbs. New Jersey and East of England both contain the inner suburbs of major cities outside their boundaries (New York and Philadelphia in the former case, London in the latter) as well as substantial rural areas. Both experienced uneven patterns of regional development and local anger over land use issues.

Policy makers in New Jersey and East of England converged on the solution of collaborative regional governance institutions for land use. Governance was attractive not only to policy makers, but also to NGOs weary of corrupt party politics and bureaucratic inaccessibility, and to developers weary of delays caused by local protest. The New Jersey State Planning Commission and the East of England Regional Assembly formulated land use plans that aimed to reconcile the needs for regional policy coherence and local participation. It was not long, however, before these institutions were beset by complaints and a generalized sense of failure. The case studies show how collaborative regional planning has inadvertently revived the unresolved crisis of the state. 
First, the underlying power of state and market remains despite the advent of regional governance. In the British case, collaborative governance bodies introduced by New Labour "have been subordinated to other policy imperatives linked to a highly managerial form of governance based on a plethora of goals, targets and performance improvement strategies" (Newman 2004: 218). This creates conflicting imperatives - "encourage participation from below but ensure you deliver on the targets imposed from above, even where these are in conflict with local views." In East of England, this conflict is most obvious with regard to centrally issued housing targets, which undermine local attempts to limit growth.

In the American case, the state never had as overt a presence, but the increasing emphasis on market solutions since the Reagan years leads to a similar charge. New Jersey planning is based on "smart growth", whose goal is to achieve a balance between targeted growth and open space preservation by means of voluntary collaboration and market incentives. In their analysis of smart growth in the Boston region, Krueger and Gibbs note that the delivery mechanisms undermine the goals, perhaps intentionally: "...one could read smart growth as a half-hearted effort to appease environmental and social welfare interests through the rhetoric of sustainability, while allowing the 'hidden hand' to work its own magic" (1271). In a strong housing market, they write, developers want to do what they have a template for, and that is sprawl.

The constellation of power creates problems with democratic accountability. Allmendinger and Tewdwr-Jones describe Labour's transfer of planning responsibility to the English regions in the late 1990 s as a political move to maintain central control while "downloading" conflict to the regional level. This helped Labour avoid alienating the competing factions of their support, namely the development industry and anti-development shire residents (1399). In the American case, state planning uploaded local conflict to the regional level, taking the heat off local market actors who were driving development choices. Regional governance 
institutions and local politicians lack the power to shape the agenda but are held accountable for outcomes.

This situation raises unresolved legitimation problems from the earlier crisis of the state. Here the different interpretations of the crisis laid out by Berger reemerge with new relevance. American and British governments in the 1970s defined the problem as inadequate provision of economic benefits or services, brought on by a plethora of conflicting societal demands. It thus made sense to unburden the state of responsibility for providing some services and to find more cost-effective ways of supplying others. Land use regimes in both countries still define quality of life largely in terms of providing adequate services to match the rate of growth (Krueger and Gibbs 2008: 1267; While, Jonas, \& Gibbs 2004). But as Berger points out, the widespread popular anger at the state had only partially to do with inadequate service provision: "This was a protest not against the failure of state and society to provide for economic growth and material prosperity, but against their all-too-considerable success in having done so, and against the price of this success" (1979: 32). She cites as evidence the fact that the protest arose everywhere before the economic downturn of the 1970s.

This was the heyday of grassroots activism on environmentalism, civil rights, peace, and other issues. To some activists, the crisis had more to do with overgovernability - the state intervened too much in society. Devolving decision making to private actors or lower levels of government would seem to be a solution. For many, however, the discontentment ran deeper. The citizen protest of those years may have been due at base to a crisis of inappropriateness. It involved a critique of the values underlying the liberal economic regime and a plea for a new definition of quality of life that included more than economic growth (Inglehart 1977; Norris 2002; Castells 1978; Harvey 1985). To the extent that those values underlie contemporary collaborative regional institutions for land use, they keep the legitimation issue alive. In East of 
England and New Jersey, disgruntled citizens perceive the values of government and industry to be fundamentally at odds with the goals of citizen empowerment, community, and environmental quality.

In the context of state-citizen politics of the past forty years, the "post-political" emphasis of the new governance institutions is also problematic (Swyngedouw 2007). It may be effective at shielding the state from societal demands. But the earlier protest was also a critique of power: where state or market dominated decision making, the argument went, citizen values would be neglected (Guggenberger and Kempf 1984; Habermas 1987: 374-403; Hager 2007). This is why protesters were so invested in grassroots democratic decision making - they linked it directly to quality of life outcomes. Critics of the state rejected traditional political channels, but not political participation per se. Their vision was deeply political. According to Berger, "The new groups believe that their objectives can only be reached through politics, but through democratic, participatory politics" (1979: 39). They tended to reject traditional channels of citizen participation - parties and parliaments - as part of the oppressive apparatus. The new regional land use institutions, in which government representatives negotiate directly with community stakeholders - would seem to be right up their alley. But this would only be true if the perceived dominance of bureaucratic or economic interests could be overcome or at least confronted within the collaborative body. The "post-political" form prevents that from happening. The protesters of the 70s and 80s did not want to eliminate conflict. Indeed, they were suspicious of government efforts to depoliticize issues. Their protest was about exposing the political nature of decisions embedded in technocratic or market decision making forms and opening up those institutions to political discussion; it was to "render power visible" and confront it openly (Melucci 1988: 250). When contemporary governance institutions try to overcome politics by 
limiting their discussion to specific concrete problems without confronting the broader issue of state or market dominance, they leave these tensions unaddressed.

Alleviating the legitimation problem would require the recognition that participants have fundamentally different values that might not easily be reconciled but that must at least be acknowledged. The British and American governments have offloaded value conflict to the regional level (from above in the former case, from below in the latter) but have not provided a forum, in the East of England Regional Assembly or the New Jersey State Planning Commission, for expressing or resolving it. It would be up to protest groups outside the institution to raise the meta-level issues, sometimes in opposition to the collaborative regional body. The suggestion by some academics (Pharr and Putnam 2000) that citizens reject these bodies because of poor policy performance puts the cart before the horse. These institutions, their critics argue, cannot be effective against sprawl because those who have the power to set the rules value development to the exclusion of other community interests.

The following case studies show how these issues unfold in the two regions. Case study research is most relevant in projects, such as this one, where the context of the phenomenon is crucial to the inquiry (Yin 2003: 2). The perspectives of a range of participants, as well as observation of the collaborative bodies in action, are important supplements to secondary source material for understanding how governance works in practice. I used a multi-method approach, including document research, participant observation, and 27 semi-structured, open-ended interviews over a five-year period, 13 for the U.S. case and 14 for the British case. The interview partners were selected to encompass the spectrum of participants and levels of governance. They included government actors, business and community stakeholders, and NGOs. The semi-structured interviews allowed the themes most important to the interviewees to emerge. Of course, issues of subjectivity may arise in any work involving interviews. I checked 
and supplemented interviewees' cited statements where possible with other forms of information (Huberman and Miles 2002), likewise checking secondary source accounts against the stated experiences of participants.

\section{(A) Case studies \\ (B) East of England}

In the 1990s British policy makers turned to regional planning as a way to provide more flexibility, with an emphasis on evening out population growth and economic opportunity. The Major government established "a centralized kind of regional planning” in 1994 by constituting regions that imperfectly followed traditional lines and establishing Government Offices (GOs) for the Regions in England (P. Hall 2002: 96). Taking their cues from the central government, these new regional bureaucracies produced "Regional Planning Guidance," a framework to coordinate local planning. In 1997, the Blair government added Regional Development Agencies (RDAs), whose mission was to foster economic development and employment. There was no easy way for the regional planning and development authorities to work together (Allmendinger \& Tewdwr-Jones 2999: 1394). Blair also stressed more direct citizen involvement in governance. The idea of regional legislatures had been discussed for some time. New Labour finally implemented them, creating regional assemblies as a way to coordinate government activities at the regional level and to involve local communities more in spatial planning.

Regional assemblies exemplify the move from government to governance. In the East of England Regional Assembly, representatives are nominated by their local governments according to the percentage of votes each party has received in the most recent local elections (EERA 2005: 3). Balancing the partisan interests is a large group (currently 32 of 105) of 
community stakeholder representatives from a range of societal organizations. EERA has thus brought stakeholders and the various regional bureaucracies together to coordinate regional planning. It passed a legally binding regional plan that was considered a model for others.

Nevertheless, EERA has not escaped the persistent criticism leveled at the regional assemblies. They are attacked from above for failing to integrate economic and spatial policy effectively and to establish clear lines of accountability. They also lack legitimacy with local populations and local officials, to whom they tend to appear less as representative legislative bodies than as another layer of government operating largely beyond public control (Department for Business Enterprise and Regulatory Reform (BERR) and Communities and Local Government (CLG) 2007: Ch. 6). In July 2007, the government announced that the regional assemblies will be disbanded in 2010 and their planning functions given to RDAs. These will each be responsible for producing a single, integrated regional plan incorporating economic, social, and environmental elements (BERR and CLG 2007: 95). Rather than following the stakeholder model of the regional assembly, it is proposed that the RDA negotiate planning with a "Local Authority Leaders' Board" composed of a subset of local leaders (CLG 2008: 16). Large development projects (power plants, airports, highways) will be evaluated by a separate, independent Infrastructure Planning Commission (IPC).

EERA's difficulties stem in part from the context of state power in which it must operate. The regional assembly was not free to set its own targets for growth. The Office of the Deputy Prime Minister, which was in charge of national-level planning, directed East of England to add 478,000 new housing units by 2021 (EERA 2004). The centrally formulated targets are a poor fit for the demographic and infrastructural realities of the region (interview with Corinne Meakins, Director, Campaign to Protect Rural England (CPRE) East of England, 21 June 2005; While, Jonas, \& Gibbs 2004: 296-297). EERA also lacked authority over the final version of 
the plan. The government-appointed inspector and the Minister both had the authority to alter it unilaterally. The final East of England plan was released in May 2008 with even higher housing targets than those in the draft plan (GOEE 2008: 28). The coming changes to the system of regional governance will not correct this problem. The new regional plans will be subject to approval by two different Secretaries of State (BERR and CLG 2008). Large infrastructure projects, which tend to be most controversial locally, will be removed from the general planning process altogether and given to another quango in order to expedite their completion.

The British government has thus tried to shift accountability for planning to the regional level while strengthening its underlying power at the center. The limited scope of EERA's planning authority has come as a shock to many local participants. The Blair and Brown governments both promised to include citizen voices directly in their planning, to make the process more "bottom-up" and collaborative. In a certain sense this has occurred. But there is a "huge caveat" in that the local authorities are statutorily bound by a regional plan over which elected officials and the general public have little influence (interview with John Dowie, GO East of England Director of Planning and Transport, 23 June 2005) and whose housing targets most in the region vehemently opposed. Lacking access to higher-level decision makers, residents tend to take out unpopular planning decisions on local elected officials and even MPs (Meakins interview). It is therefore unsurprising to hear local councillors refer to Regional Assemblies as "expensive, unnecessary, and unaccountable" (Lord Hanningfield, EADT 2007). As of 2010, land use planning in East of England will be folded into an agency whose main function is to promote economic development. Consolidating regional authority in the RDA will reduce the need for coordination among the various regional agencies. This may aid accountability in one sense. In another sense, it may widen the disconnect between power and accountability by framing land use issues narrowly and from above. The collaborative model 
that officially recognizes and includes stakeholders will give way to negotiation between local leaders (through the Leaders' Board) and RDA. Further, the IPC would take the most controversial developments out of the hands of local politicians, not by post-political collaboration, but by fiat, in the name of streamlining the approval process. A former EERA chairman fears that "the important decisions on planning, transport, and housing development will now be taken centrally by closed quangos in Whitehall rather than in the region" (Sue SidaLockett, EADT 2007).

The accountability problems have potentially far-reaching consequences for the legitimacy of collaborative regional planning. EERA and local officials have to answer for decisions actually taken elsewhere. Despite its inclusiveness, the regional planning process also limits the nature of issues that can be raised. The draft East of England Plan received 26,000 responses during the public comment period. The planning inspector then had to select 25 participants for the public hearing. Those groups hoping to be invited had to demonstrate that they had behaved "reasonably" on the subject in the past (Meakins interview). This eliminated any serious dissent from the proceedings. At the end of the process, the planning inspectorate published its recommendations, in which the housing figure had risen to 506,000. To those opposed to this scale of development there remained the threats of negative publicity and local political mobilization. The central government "can ignore what's been said and do what it likes," says an NGO participant. "What we try to do is demonstrate to them that there is a political risk" to doing so (interview with Sean Traverse-Healey, Vice-Chair, CPRE East of England, 21 June 2005). Thus, the critique of growth was articulated mostly outside the collaborative institution. There has been much local resistance to the EERA plan, particularly to the housing proposals and large infrastructure projects such as the Stansted Airport expansion, as evidenced by the large number of responses critical of the draft. 
EERA was also unhappy with the centrally imposed housing figures. It temporarily suspended its endorsement of its own draft plan, arguing that the national government had failed to commit to funding the infrastructure such housing increases would require. But to many residents who opposed the plan, the problem was not a lack of adequate infrastructure - it was the one-sided commitment to growth itself. Their objections were not just NIMBY, but also included concerns about the environment, social inequality, and community solidarity. The EU concept of sustainability is based on the idea that "economic growth, social cohesion, and environmental protection go hand in hand" (EU Commission 2001). There is a strong feeling among local authorities and concerned citizens that the environmental and social legs will come up short (interview with Peter Chillingworth, councilman and CPRE member, Colchester, 30 June 2005). A local councilwoman explained, for example, that with all the growth, lack of rootedness in communities is a major concern. The proposal to build onto existing communities and swap pieces of green belt, she said, will exacerbate social problems (interview with Penny Smith, Councilwoman, Epping Green, 29 June 2005). Others pointed out that development in the green belt would divert resources from regeneration efforts in East London and likely accelerate the exodus from rundown areas of the city (Traverse-Healey interview). As for the environmental leg, national-level NGOs point out that there is no clear linkage of recent climate change legislation to the duties of the proposed Infrastructure Planning Commission (Friends of the Earth 2008: 2). Future spatial planning, consolidated in the RDAs, is bound to privilege development interests even more. It is not just that decisions are taken centrally or that the central government fails to provide adequate infrastructure; it is also that only a narrow set of goals is included in the purview of the institution. It can be seen as a crisis of inappropriateness in the Berger sense. 
There is no clear way to make the other planning goals and the confrontation of underlying values raised at the local level a real part of the agenda of the regional planning body (interview with John Preston, head of planning and economic development for Epping Forest District Council, 29 June 2005). This problem stokes the feeling among locals that regional planning has not succeeded, not because it failed to produce a plan or to function collaboratively, but at base because the rules of the game were set by the central state according to a narrow set of nonnegotiable economic goals. It is clear that coherent regional planning and substantive local participation are not always compatible. But rather than working through the differences, collaborative regional planning has revived the critique from the 1970s that the state cannot respond adequately to noneconomic quality of life concerns.

\section{(B) New Jersey}

The most densely populated American state, New Jersey has both a severe sprawl problem and an exceptionally strong ideology of local self-government or "home rule" (Salmore and Salmore 1998: 201). Much of the power to make land use decisions has been delegated to municipal governments. Frustrated residents have passed an array of open-space tax referenda at municipal, county, and state levels and attempted to "downzone" what undeveloped property is left. By the early 1990s, more local governments had approved open-space taxes in New Jersey than in any other state (Shutkin 2000: 214).

New Jersey's state planning apparatus dates from the mid-1980s, when a State Supreme Court decision mandating affordable housing forced the issue (Haar 1996). Here it was not a matter of devolving power from the national level. Power lay with market actors all along, but the regulatory climate changed over time. State planning was initiated in a fairly anti-regulatory environment. The state thus tried to create a cooperative system based on voluntarism. The New 
Jersey State Planning Commission, like EERA, exemplifies the move from government to governance; its 17 members include seven representatives of state agencies, two municipal and two county representatives, one professional planner, and five citizen appointees. Its major task was to compose and implement a State Development and Redevelopment Plan.

The State Plan was first published in 1992. It is a nonbinding template for growth whose original purpose was to break the pattern of urban decline and suburban sprawl by channelling development into denser "centers" and preserving open space around them. The State Plan is updated regularly through a collaborative process of "cross-acceptance" with county and municipal planning boards. Cross-acceptance allows the state to guide planning without violating home rule. Local communities continue to write their own land use plans, but they do so in the context of a "public participation process whereby all levels of government compare the content of their local planning efforts to that of the proposed [State Plan] and then negotiate changes in how the proposed goals and policies would be applied locally" (Barnes 1997: 5). It is, as Robert Fishman notes, "a kind of invitation to each of these local units to engage in a statewide 'conversation' to reexamine needs and priorities and bring them into harmony with the plan's regional goals" (Fishman 2000: 119). It is supposed to promote cooperation and limit adversarial politics without too heavy a government hand.

The voluntary nature of the plan, however, leaves regulatory power fragmented at the state level and allows developers to continue to control land use. State agencies have had little incentive to coordinate their planning efforts. This creates problems for local governments trying to conform to the plan: "Local government has to be able to say I can do all the things in the State Plan, and then I can be guaranteed that the Department of Transportation won't build a highway through my town" (interview with Candace Ashmun, 7 August 2003). State government has tried recently to promote a more coherent approach. In 2002, the governor 
created a Smart Growth Policy Council whose purpose was "to ensure that state agencies incorporate the principles of Smart Growth and the State Plan into their functional plans and regulations." This effort foundered on the very bureaucratic fragmentation it was designed to overcome. Ultimately, writes one regional expert, the council "did very little, in part because of conflicts between competing state agencies who felt threatened by the idea" (Yaro 2007). These conflicts carry over to the State Planning Commission itself; the seven agency heads on the commission are often accused of protecting their own turf rather than pursuing the broader state planning agenda (Candace Ashmun interview; interview with Julia Somers, Executive Director, New Jersey Highlands Coalition, 9 October 2008). Without a clear line of authority and a means of enforcing state policy, the plan is doomed to "near irrelevance" (interview with Andrew Strauss, planner, 23 July 2003).

State planning has not changed incentives adequately for developers. The main tenet of "smart growth" is that development ought to be guided to places where supporting infrastructure already exists and away from rural and environmentally sensitive areas (New Jersey Office of Smart Growth, www.nj.gov/dca/osg/smart). The guidance has not been strong enough to steer industry toward urban areas in need of regeneration and employment opportunities. Instead, industrial campuses have proliferated in semi-rural areas where local resistance is high (Jover 2001). This is partly because the collaborative process has not protected land use decisions from legal challenges. Municipalities designate different uses for land, building densities, and so forth through local zoning. If a municipality bases its zoning on a local land use plan that is consistent with the State Plan, the zoning has a better chance, but is not guaranteed, to withstand lawsuits. Townships trying to limit sprawl have tended to win in state court recently, but few local elected officials have the stomach or the finances for a protracted legal battle with developers (interview with Carleton Montgomery, Executive Director, Pinelands Preservation Alliance, 29 July 2003). 
And, as Krueger and Gibbs explain for a similar case in Massachusetts, developers favor what is easiest for them, which is sprawl development (2008: 1271). Collaborative state planning thus does not replace an adversarial process that favors the participant with the most money; power still lies ultimately with private development interests that promote sprawl. Here, as in East of England, a narrow set of goals is served despite the inclusive policy making form.

It is clear that fragmented control of land use produced regionally incoherent development patterns and reinforced inequalities in housing and employment. But New Jersey officials tried to shift accountability for planning upward without giving the regional body the authority to implement its own decisions. Planning thus remains piecemeal and incoherent despite the advent of a collaborative state institution. Local elected officials are blamed for sprawl by angry residents and are also routinely sued by developers, even when their policy choices conform to the State Plan. Voters have ousted a number of township governments for their failure to control growth (Jover 2001; Coyne 2003).

Accountability problems revive the legitimation issue. As in East of England, the New Jersey state planning process limits the nature of the issues that can be raised. It is difficult for members of local planning boards, most of whom are laypeople in voluntary positions, to advocate successfully for changes in the plan. Municipal politicians, too, are no match for the professionals employed by developers. The professionals on which municipalities rely for information are generally connected to builders as well (interview with Mike Bolan, planner, Banisch Associates, 7 July 2003). The terms of the conversation are set by economic actors who favor growth. Local officials are invited into the conversation but lack the resources to participate independently. As a result, only one set of local interests is articulated effectively.

For many residents, the results seem to reflect bias in the planning system. An NGO leader says, "sprawl is intimately related to the malfunctioning of our democracy" (interview 
with William DeCamp, Jr., President, Save Barnegat Bay, 8 August 2003). As in the English case, the opposition to sprawl is more than NIMBY. It indicates a crisis of inappropriateness; the solutions offered by governance institutions do not reflect the full range of citizen goals. "Quality of life" became the rallying cry of local communities nationwide that rose up against sprawl in recent years (Egan 1998; T. Hall 1999). This term connotes environmental sustainability, a sense of community, neighborliness, and a link with a more rural past, in addition to economic well-being (Kunstler 1993; Jover 2001). New Jersey voters' willingness to approve open-space taxes for local land purchases - on top of the highest property taxes in the nation - is testimony both to the salience of noneconomic aspects of quality of life and to residents' skepticism that state planning can provide them.

As in East of England, dissent arises largely outside the planning body. Citizen participation mostly takes the form of grassroots protest after permits have been granted. While local activists demand a more substantive role for citizens, many do not believe that a planning system so infiltrated by development interests can produce sustainable policy even where the process is consensual (interview with Michele Donato, planning board attorney, 8 July 2003). As a local councilwoman put it, "If one side's bottom line is profit, then there can be no meeting of the minds" (interview with Eileen Swan, Lebanon Township Committeewoman, 8 September 2003). As in the EERA case, New Jersey state planning does not provide a forum for debate of the values underlying the planning system; it thus leaves the legitimation issue to be contested elsewhere.

\section{(A) Conclusion}

Collaborative regional institutions for land use arose in the UK and the USA in the context of a reworking of state-societal relations after the "crisis of the state." They seemed to 
address the common wish to overcome adversarial politics and command-and-control policy making and to build partnerships between public officials and local communities that would help alleviate sprawl. As the East of England and New Jersey cases show, however, the collaborative regional institutions are embedded in an environment still structured by central state or market power that limit their policy options as well as their ability to achieve democratic legitimacy. The collaborative form may actually mask the extent to which these factors still determine policy outcomes and may thus increase public frustration.

Contemporary sprawl debates revive the issues of underlying power, accountability, and legitimation raised by the anti-state protests of the 1970s and 80s. In the USA particularly, state and market are often considered opposites, but they are both viewed as oppressive (and allied) by many citizens, setting the parameters of policy making outside the influence of those who must live with the consequences. In East of England, regional planning suffers from having to accept mandates, such as rapid housing growth, handed down by Whitehall. This undermines both the policy making ability and the legitimacy of the collaborative body. In New Jersey, regional planning has been unable to overcome the fragmentation, at the local level and among state agencies, that allows development interests to overwhelm the collaborative process. The shift from government to collaborative governance since the 1970s has not changed the fact that state or market actors outside the regional institutions have the power to set the rules of the game.

While the underlying power has not changed, governments in both countries have tried to shift accountability to the regional level - from above in the British case, from below in New Jersey. In neither case, though, does the regional governance body provide a sufficient forum for confrontation of the different goals and values involved in planning. Ironically, in our two case studies the buck has not stopped at the regional level. Local politicians are blamed for the failings of the EERA and the New Jersey State Planning Commission. In both cases the context 
in which the collaborative institution operates undermines not only its own legitimacy, but also the legitimacy of local elected officials, thus weakening a link with the public.

These problems may not be confined to the institutions analyzed here. I would argue that no "post-political" collaborative body would be able to take up meta-level issues effectively; they are explicitly designed not to do so. This is one reason why, in the age of governance, the political scene is still rife with accusations of government overreach in Britain and corporations run amok in the USA. In our cases, reconciling the oft-competing aims of coherent regional planning and substantive citizen participation is a difficult task. If policy makers view the problem as ungovernability - too many conflicting political demands - it makes sense for them to contain conflict by manipulating the level and form of discussion, and by setting the parameters to issues that can be resolved most easily. If, as I believe the case studies show, it is more a problem of inappropriateness as Berger, Harvey, and Castells describe, then the solution would be more politics, not less. The unresolved quality of life issue, which the earlier protest movements connected closely with grassroots democratic politics, emerges starkly in current land use issues. As in Berger's examples, it is not so much a case of too many or conflicting demands; rather, the demands are of a nature that defies an effective state response. The new governance spaces opened by regional land-use bodies are not political spaces in the sense of offering a forum for contesting values issues. The alternative is for quality of life issues to be contested mainly outside and sometimes against the collaborative body, as they are in our cases, and for sprawl controversies to contribute to a recurring narrative in both countries on the inaccessibility of power.

\section{(A) References}


Allmendinger, P. and M. Tewdwr-Jones (2000) New Labour, new planning? The trajectory of planning in Blair's Britain. Urban Studies 37.8, 1379-1402.

Barnes, B. (1997) Complete guide to planning in New Jersey. American Planning Association, Trenton.

Berger, S. (1979) Politics and Antipolitics in Western Europe in the Seventies. Daedalus 108.1, 27-50.

Castells, M. (1978) City, class and power. St. Martin's, New York.

Commission of the European Communities (2001) A sustainable Europe for a better world: a European Union strategy for sustainable development. COM 264, 15 May. Brussels.

Cox, K. (2004) The politics of local and regional development, the difference the state makes and the US/British contrast. In A. Wood and D. Valler, Governing local and regional economies: institutions, politics and economic development. Ashgate, Burlington, VT.

Coyne, K. (2003) Roosevelt's New Deal. New Jersey Monthly (May), 48-51, 77-78.

Departments for Business Enterprise and Regional Reform (BERR), and Communities and Local Government (CLG) (2007) Review of sub-national economic development and regeneration.

DBERR, London.

Departments for Business Enterprise and Regional Reform and Communities and Local Government (2008) Prosperous places: taking forward the review of sub-national economic development and regeneration. BERR, London.

Department for Communities and Local Government (2008) Prosperous places. The Government response to public consultation. CLG, London.

East Anglian Daily Times online (2007) Axe falls on regional assembly (18 July). http://www.eadt.co.uk. 
East of England Regional Assembly (2004) East of England plan: Draft revision to the regional spatial strategy (RSS) for the East of England. EERA, Bury St Edmunds.

East of England Regional Assembly (2005) East of England Plan, Media Pack. EERA, Bury St

Edmunds.

Egan, T. (1998) The new politics of urban sprawl. The New York Times (15 November), 1.

Fishman, R. (2000) The death and life of American regional planning. In B. Katz (ed.), Reflections on regionalism, Brookings, Washington, DC.

Friends of the Earth (2008) Climate change and the planning bill (briefing). FoE, London. Government Office for East of England (2008) East of England plan: the revision to the Regional Spatial Strategy for the East of England. London.

Guggenberger, B. and U. Kempf (eds.) (1984) Bürgerinitiativen und repräsentatives System [Citizen initiatives and representative system], Westdeutscher Verlag, Opladen.

Haar, C. (1996) Suburbs under siege: race, space, and audacious judges. Princeton University Press, Princeton.

Habermas, J. (1987) The theory of communicative action, v. 2. Beacon Press, Boston.

Hager, C. (2007) Three decades of protest in Berlin land-use planning, 1975-2005. German Studies Review 30.1, 55-74.

Hall, P. (2002) Urban and regional planning. 4th edition. Routledge, New York.

Hall, T. (1999) Stopping suburban sprawl. New Jersey Law Journal 158.1 - index 60, 1-4.

Harvey, D. (1985) Consciousness and the urban experience. Johns Hopkins, Baltimore.

Hirst, P. (2000) Democracy and governance. In J. Pierre (ed.), Debating governance, Oxford.

Huberman, A. and M. Miles (eds.) (2002) The qualitative researcher's companion, Sage, Thousand Oaks, CA. 
Huntington, S. (1975) The United States. In M. Crozier, S. Huntington, J. Watanuki (eds.), The crisis of democracy: a report on the governability of democracies to the trilateral commission, NYU Press, New York.

Inglehart, R. (1977) The silent revolution: changing values and political styles among Western publics. Princeton University Press, Princeton.

Innes, J. and D. Booher (2003) Collaborative policymaking: governance through dialogue. In M. Hajer and H. Wagenaar (eds.), Deliberative policy analysis: understanding governance in the network society, Cambridge, New York.

Jonas, A. and A. Weil (2007) Greening the entrepreneurial city? Looking for spaces of sustainability politics in the competitive city. In R. Krueger and D. Gibbs (eds.), The sustainability development paradox: urban political economy in the United States and Europe. Guilford, New York.

Jover, T. (2001) Hopewell Township/Merrill Lynch: a case study of land use in New Jersey. New Jersey Future online: http://www.njfuture.org.

Kraft, M. (2009) Cleaning Wisconsin's waters: from command and control to collaborative decision making. In D. Mazmanian and M. Kraft (eds.), Toward sustainable communities, 2nd ed., MIT Press, Cambridge.

Krueger, R. and D. Gibbs (2008) 'Third wave' sustainability? Smart growth and regional development in the USA. Regional Studies 42.9, 1263-1274.

Kunstler, J. (1993) The geography of nowhere. Simon and Schuster, New York.

Marcuse, H. (1964) One-dimensional man: studies in the ideology of advanced industrial society. Beacon Press, Boston.

Mazmanian, D. and M. Kraft (eds.) (2009) Toward sustainable communities, 2nd ed. MIT Press, Cambridge. 
Melucci, A. (1988) Social movements and the democratization of everyday life. In J. Keane (ed.), Civil Society and the State, Verso, London.

New Jersey Office of Smart Growth Website, www.nj.gov/dca/osg/smart.

Newman, J., M. Barnes, H. Sullivan, and A. Knops (2004) Public participation and collaborative governance. Journal of Social Policy 33.2, 203-23.

Norris, P. (2002) Democratic phoenix: reinventing political activism. Cambridge University Press, Cambridge.

Offe, C. (1984) Contradictions of the Welfare State, MIT Press, Cambridge.

Peck, J. and A. Tickell (2002) Neoliberalizing space. Antipode 34.3, 380-404.

Pharr, S. and R. Putnam (eds.) (2000) Disaffected democracies: what's troubling the trilateral countries? Princeton University Press, Princeton.

Salmore, B., and S. Salmore (1998) New Jersey politics and government. 2nd ed. University of Nebraska Press, Lincoln.

Shutkin, W. (2000) The land that could be. MIT Press, Cambridge.

Swyngedouw, E. (2005) Governance innovation and the citizen: The Janus face of governancebeyond-the-state. Urban Studies 42.11, 1991-2006.

Swyngedouw, E. (2007) Impossible 'sustainability' and the postpolitical condition. In R. Krueger and D. Gibbs (eds.), The sustainable development paradox: urban political economy in the United States and Europe, Guilford, New York.

Taylor, M. (2007) Community participation in the real world: opportunities and pitfalls in new governance spaces. Urban Studies 44.2, 297-317.

Vig, N. (2006) Presidential leadership and the environment. In N. Vig and M. Kraft (eds.), Environmental policy: new directions for the twenty-first century, 6th ed., CQ Press, Washington, DC. 
Weir, M. (2000) Planning, environmentalism, and urban poverty: the political failure of national land-use planning legislation, 1970-1975. In R. Fishman (ed.), The American planning tradition: culture and policy, The Woodrow Wilson Center Press, Washington, DC.

While, A., A. Jonas and D. Gibbs (2004) Unblocking the city? Growth pressures, collective provision, and the search for new spaces of governance in Greater Cambridge, England. Environment and Planning A 36.2, 279-304.

Yaro, R. (2007) Spitzer's new smart growth cabinet could be new model for economic development. Spotlight 6.22 online.

Yin, Robert K. (2003) Case study research, 2nd ed. Sage, Thousand Oaks. 